\title{
Determinants of farmers' loyalty to dairy processors in Minas Gerais, Brazil
}

\author{
Andre Rozemberg Peixoto Simões ${ }^{*}$ (iD) Charles Frederick Nicholson ${ }^{2}$ iD \\ Janderson Damaceno dos Reis ${ }^{3}$ iD Roberto Max Protil ${ }^{3}$ iD \\ André Luiz Julien Ferraz ${ }^{1}$ iD Dalton Mendes de Oliveira ${ }^{1}$ iD
}

${ }^{1}$ Programa de Pós-graduação em Zootecnia, Universidade Estadual de Mato Grosso do Sul (UEMS), 79200-000, Aquidauana, MS, Brasil. E-mail: andrerpsimoes@hotmail.com. *Corresponding author.

${ }^{2}$ Nijmegen School of Management, Radboud University (RU), Nijmegen, Netherlands.

${ }^{3}$ Departamento de Economia Rural, Universidade Federal de Viçosa (UFV), Viçosa, MG, Brasil.

\begin{abstract}
The current study explores variables associated with the loyalty of dairy farmers to dairy processors in the Brazilian context. A multivariate discrete choice (Logit) model and alternative formulations assess the associations between loyalty metrics and farm and processor characteristics for a sample of 32 dairy farmers in 16 municipalities at the Zona da Mata in Minas Gerais. Twenty-two dairy processors were identified as milk buyers in the area studied, but each farmer indicated that they could sell to an average of five alternative buyers of milk. Farmers'attributes such as production scale or the technological level are not statistically significantly associated with loyalty in this sample. The current milk price paid to farmers in our sample is not associated with increased loyalty (sales to a single processor for 6 or more years) in all estimated models; although, further research on this impact is merited to inform buyer-pricing policy. Variables associated with increased loyalty include payment of premiums for quality, farmer years of experience and cooperation among farmers in the purchase of inputs. Delayed payment is associated with reduced loyalty. We could not determine the effect of participation in technical assistance programs offered by processors on loyalty, because in our sample all farmers received free university-provided technical assistance. The payment of a premium based on milk volume was also unassociated with loyalty determination. The small size of our sample limits the ability to generalize our results but provides exploratory results that facilitate future investigation.
\end{abstract}

Key words: dairy, loyalty, vertical coordination.

Determinantes da fidelidade dos produtores de leite aos laticínios em Minas Gerais, Brasil

RESUMO: $O$ objetivo deste estudo é explorar as variáveis importantes associadas à fidelidade dos produtores de leite aos laticínios no contexto brasileiro. Um modelo de escolha discreta multivariada (Logit) e formulações alternativas foram usadas para avaliar as associações entre métricas de fidelidade e características de fazendas e processadores em uma amostra de 32 produtores de leite de 16 municípios da Zona da Mata, em Minas Gerais. Vinte e dois laticinios foram identificados como compradores de leite na região estudada, entretanto, cada produtor indicou que tem, em média, a possibilidade de vender o leite para cinco empresas diferentes. Os atributos dos agricultores, como escala de produção ou nível tecnológico, não foram estatisticamente associados significativamente à fidelidade. O preço atual do leite pago aos agricultores nessa amostra não está associado a probabilidade de aumento da fidelidade (vendas para um único laticínio por seis anos ou mais) em todos os modelos estimados. No entanto, pesquisas adicionais sobre esse impacto são necessárias para subsidiar políticas de preços aos produtores. As variáveis associadas ao aumento da fidelidade incluem pagamentos de prêmios pela qualidade, anos de experiência dos agricultores e a cooperação entre os agricultores na compra de insumos. O atraso no pagamento está associado à redução de fidelidade. Não foi possivel determinar o efeito da participação em programas de assistência técnica oferecidos pelos processadores na fidelidade, provavelmente porque todos os produtores estudados recebem assistência técnica de graça de uma Universidade. O pagamento de prêmios com base no volume de leite também não foi associado à determinação da fidelidade. O pequeno tamanho de nossa amostra limita a capacidade de generalizar nossos resultados, mas fornece resultados exploratórios que facilitam investigações futuras.

Palavras-chave: laticinios, lealdade, cadeia produtiva.

\section{INTRODUCTION}

Brazil had around 1.2 million dairy farmers in 2017 (IBGE, 2017), with significant heterogeneity in technology and production scale (SILVA et al., 2016; SIMÕES; REIS; AVELAR, 2017; TELLES; BACCHI; SHIMIZU, 2017). These farmers sell milk to cooperatives, international companies and small local plants, and the competitive landscape for milk procurement has changed markedly in the past two decades. Because the macroeconomic transformation observed beginning in the 1990s (greater commercial openness, inflation control, and the logistics improvements that allow the transportation of dairy 
products such as UHT milk over long distances), companies now compete more vigorously for the raw milk needed to supply their processing plants (BREITENBACH \& SOUZA, 2015; SCALCO \& BRAGA, 2014).

In this more competitive context, dairy processors desire to retain an optimum number of milk suppliers (farmers) and with characteristics that minimize their logistics costs. Suppliers with higher volumes, easier geographic access and higher milk quality are preferred. However, because formal contracts are not a common practice in the Brazilian dairy supply chain (CALEMAN et al., 2014), competition among processors for farm milk supplies can allow farmers to act opportunistically, switching among milk buyers as better prices or other incentives are offered. The degree of switching by farmers has important implications for both farmers and processing companies, affecting costs, returns and adequacy of milk supplies.

The stability of relationships with suppliers is thus important to milk processors, but its determinants are not well understood. Loyalty between dairy farmers and processors is relevant in Brazil because the limited degree of loyalty is considered a main impediment for improved coordination and competitiveness of the dairy supply chain (CARVALHO, 2018). Further, processors have a particular interest in knowing the determinants of loyalty to inform their efforts to reduce logistics and the retention costs of milk suppliers. More, there are limited analyses of factors affecting farmer loyalty to product buyers, for which the dairy in Brazil is one specific example. An improved understanding of the factors affecting loyalty and switching behavior may provide insights about the design of programs to increase farmer loyalty (BEBER et al., 2019).

Different approaches have been used to assess loyalty in other contexts than the dairy supply chain, and the study of BONIFACE et al. (2010) was one of the first adapting the concepts from a businessto-consumer context (B2C) to the relationship of dairy farmers and processors. They defined loyalty as the motivation of dairy farmers to continuously sell milk and engage in long-term relationships with their buyers. The dimensions of price satisfaction defined as price fairness, price transparency, price reliability, price-quality ratio, and relative price (BONIFACE et al, 2012) influence producers' trust in buyers; and consequently, enhance loyalty (MUTONYI et al., 2016; SUSANTY; BAKHTIAR; MUTI, 2017). Price is often considered an important variable influencing the loyalty of farmers to processors, but the provision of services such as technical assistance, quality bonus, making timely payments, and good communication with suppliers are also pointed as loyalty enhancing practices in previous studies (BREITENBACH et al., 2017; CHADDAD, 2007; FAŁKOWSKI, 2012; GYAU et al., 2011; SIMÕES \& PROTIL, 2015).

Thus, the previous studies provide clues about what variables to use in measuring the likely of a farmer being loyal, but as highlighted by FAŁKOWSKI (2012) the current literature lacks analyses based on continuous metrics of loyalty. Given the practical importance of loyalty determinants and the limited knowledge base, the current study explores variables associated with the loyalty of dairy farmers to the dairy processors, focusing on farmer and processor attributes in a small rural community in Minas Gerais-Brazil.

\section{MATERIALS AND METHODS}

The loyalty of a farmer to a buyer can be framed as a discrete choice problem with two options: remain with the current buyer or switch to an alternative buyer. The analysis of such problems involving dichotomous responses usually applies econometric models of discrete choice. In dairy systems, for instance, these types of models have been used to assess technology adoption (EL-OSTA; MOREHART, 2000; GACHANGO et al., 2014), and exit decisions (BRAGG \& DALTON, 2004), and choices about coordination mechanisms (ABDULAI; BIRACHI, 2009) among others. The most common models used for binary choices are the Logit and Probit in which the relationship between probability and the predictors is nonlinear (sigmoidal), and they differ only by the specification of the cumulative distribution function used.

In estimating the likelihood of loyalty of farmers to processors $(Y)$, the characteristics of both must be observed; however, this variable is considered latent (non-observable) and can be defined as $Y_{i}^{*}-X_{i} \beta+\mu_{i}$ with $i=1$. Thus, $Y_{i}^{*}$ represents the dependent variable related to the loyalty of farmer $i$ to processor; $\beta$, are the parameters to be estimated in the equation; $X$, the set of independent explanatory variables of loyalty; $\mu_{i}$ the probabilistic error. The model was estimated using the maximum likelihood method with the purpose of obtaining the impact of each variable on the likelihood of occur the discrete event in its central point. The dependent variable for loyalty was calculated based on the average number of consecutive years that a farmer sells milk exclusively to a given processor. An arbitrary value of 
six years was considered the threshold for a farmer to be classified as loyal or non-loyal in the initial model. Thus, $Y_{i}-1$ if $Y^{*} \geq 6$ and $Y_{i}-0$ if $Y^{*}<6$. This limit aligns with the estimated time required for a positive return on capital invested in a new processing plant (DURLO, 2012; SEBRAE-ES, 1999). Therefore, it is highly desirable that the processor retains enough farmers (and milk supply) to become operational at least during amortization of the invested capital. Previous studies of farmer loyalty have included various personal, social, economic, and technological attributes as explanatory variables, but no consensus exists for which specific variables should be included in econometric analyses of loyalty. Thus, we selected relevant variables based on a combination of those in previous studies and informed judgment about factors probably important in the Brazilian milk-marketing context.

The eight independent variables were defined as follows. Production Experience is the number of years producing milk. Price is current milk price paid by the processor to the farmer in Reais (Brazilian currency) per liter. Technical Assistance is a binary variable that indicates whether the processor offers a technical assistance program to farmers. Joint Purchase of Inputs is a binary variable used as a proxy for the degree of horizontal coordination between farmers and equal to 1 if a farmer purchases inputs jointly with other farmers. Volume Bonus is a binary variable that indicates whether the processor pays a bonus for larger quantities of milk supplied by the farm. Quality Bonus is a binary variable that indicates whether the processor pays a price premium for higher quality milk. Quality Report is a binary variable that indicates whether farmers trust the milk quality report provided them by processors. Payment Errors is a binary variable that indicates whether farmers reported the occurrence of errors or inconsistencies in payments due for various possible reasons (discrepancies related to the volume produced, the payment of the negotiated price or other contested discounts or charges). We hypothesize that each of these variables would positively affect the loyalty variable except for Payment Errors, which would be expected to decrease farmer loyalty. We also tested in alternative estimations the variables related production scale (Volume and Cow) and efficiency (cow yield - Productivity).

We collected data through a survey of 32 dairy farmers in 16 municipalities (Araponga, Cajuri, Canaã, Coimbra, Divinésia, Guaraciaba, Oratórios, Pedra do Anta, Piranga, Porto Firme, Presidente Bernades, Senador Firmino, Teixeiras, Ubá, Viçosa and Visconde do Rio Branco, with two farmers per municipality on average) at the Zona da Mata in Minas Gerais during June 2014. Although, the data were collected six years ago, recent communications with stakeholders in the dairy supply chain indicated that the issue of loyalty remains important and the competitive context is not markedly different at present. The questionnaire included 54 questions considering farmers' attributes, the competitive environment, and processors' attributes (Appendix 1 provides the complete survey instrument). All interviewed farmers belonged to a technical assistance program promoted by the Universidade Federal de Viçosa (UFV) and staff trained by the technical assistance program administered the questionnaire to these farmers.

Our sample is small and may not be representative of the broader population to which it would be useful to generalize the results, which makes our study an exploratory assessment rather than conclusive. Alternatively, loyalty is thus phenomenon influenced by actors belonging to the same social network and loyalty analysis is most appropriately undertaken at the scale of geographic areas aligned with the distances observed for the movement of milk from farms to plants, that is, at a scale that allows for personal interaction to affect the reputation of both suppliers and buyers (ROGERS, 2003; WATTS \& DODDS, 2007). Studies based on small geographic areas make broadly generalists conclusions more difficult (SILVA et al., 2020), especially given the heterogeneity of milk production systems and socioeconomic status that exist among Brazilian dairy farmers. However, such studies can provide initial insights about retention strategies for processors and provide a basis for future studies of multiple smallerscale geographic areas.

To partially overcome the limited number of observations (due to resource constraints), we tested the robustness of our results by comparisons with five alternatives with different sets of independent variables and estimation techniques (e.g., Tobit and linear regression). For these, we modified the dependent variable to be continuous (the average number of years with the current processor (rather than the binary variable based on 6 or more years' loyalty). We also modified the independent variables to assess how alternative model formulations affected which variables were statistically significant, largely motivated by the need to keep independent variable numbers small due to limited degrees of freedom. The limited number of milk suppliers per processor also limits our ability to examine the impact of other processor 
attributes (for instance, is a cooperative, a small business or an international organization) on farmer's loyalty that could be relevant in the Brazilian context.

The comparative analysis of two groups, loyal and non-loyal farmers uses a $5 \%$ significance level. Chi-squared-tests assess frequency differences for the categorical variables and a z-test is used to determine mean differences for continuous variables.

\section{RESULTS AND DISCUSSION}

\section{Descriptive results}

Productivity characteristics varied among farms surveyed; although, these farms are larger and more productive than the average in their region. Farms produce on average 816 liters per day and production per cow is 15.2 liters/day, while the region average is 6.6 liters/cow/day, according to IGBE in 2018. In most of the cases the production systems are semi-confined (78\%), confined (16\%) and a smaller portion exclusively pasture-based $(6 \%)$. Twenty-two dairy processors were identified as milk buyers in the area studied; however, each dairy farmer indicated that they could sell to an average of five alternative buyers of milk.

By our definition of loyalty (i.e., $\geq 6$ years with current buyer), approximately $60 \%$ of the sample was classified as 'loyal', but the characteristics of the two groups differed. Although, farmers in the two groups have similar average ages (53 years), farms classified as loyal have more farming experience $(+15$ years) and more years receiving technical assistance ( +6 years). Farms classified as loyal also have higher productivity per cow (16.7 Liters/day) compared with non-loyal farms (12.9 Liters/day). No statistical difference is observed for production scale (daily production and the number of cows) despite the numerical difference between the two groups. The average milk price does not differ statistically between the two groups. Milk is the main source of income for most of the loyal farmers $(68 \%)$ and a considerably smaller proportion for non-loyal farmers (15\%). Living permanently in farm (44\% of all farmers) and schooling level do not differ by loyalty status.

\subsection{Econometric results}

In the initial logit model with a binary loyalty variable, the independent variables explain $86 \%$ of the variance of the dependent variable (probability of being loyal) and correctly predict $84 \%$ observations. The variables years of farming experience, joint purchase of inputs, quality bonus and payment delays (alternative models) are statistically significant (at the maximum of $10 \%-\mathrm{P}<0.1)$ and have marginal effects with the expected signs (Table 1).

The marginal effect of farmer's Experience indicated that more experienced farmers are associated with a higher probability of being loyal to the processor (see models: Baseline, Tobit1, Linear1 and Linear2). One explanation for that is that more experience would provide more market variable knowledge and a better understanding of processors' behavior. However, this result contrasts with, FAŁKOWSKI (2012), which did not find a statistically significant effect for this variable nor for age. The Experience variable was also not statistically significant in our models Logit 2 and Tobit 2.

The marginal effect of Joint Purchase of Inputs in the Baseline model (and all others except for the Logit2 and Linear2 models) indicate that farmers who act cooperatively are associated with an increased likelihood of loyalty. This can be related to the perception of the benefits of having partnerships among farmers and of cooperating vertically with processors. CASALI et al. (2020) highlighted that dairy farmers who did not participate in farmers' organizations operated under greater information asymmetry and were disadvantaged regarding technical support from the buyer and had a lower level of trust in the buyer. According to BREITENBACH et al. (2017), incentives for buying inputs with lower prices offered by buyer cooperatives enhanced trust and loyalty other than price incentives.

MARASCHIN \& WAQUIL (2004) pointed out that the loyalty of farmers to cooperatives does not depend on production scale or production system and highlighted that the most loyal farmers are the ones who participate in cooperative activities and the ones who have a higher perception of the importance of the institution in their activities. We also reported no significant effect for the production scale (Volume) and cow numbers (Cow) nor production system assessed through cow yield (Productivity) for most of the model specifications, and this is also in accordance with the non-significant coefficients for milk yields and for herd size used by FAŁKOWSKI (2012). In contrast, BONIFACE (2012) reported that small-scale dairy farmers in Malaysia with lower profitability and more vulnerable to dairy processors purchasing power are more willing to set longterm commercial relationships based on trust. More experienced farmers with higher production scale and profitability tend to switch the milk buyers more frequently. In European countries, BAKUCS et al. (2013) reported that large-scale farmers are more willing to establish long-term contracts and that 
Table 1 - Marginal effects estimated and the significance level of independent variables of dairy farmer's loyalty.

\begin{tabular}{|c|c|c|c|c|c|c|c|c|c|c|c|c|}
\hline & \multicolumn{2}{|c|}{$\begin{array}{l}\text { Baseline Logit } 1 \\
----(6 \text { years)---- }\end{array}$} & \multicolumn{2}{|c|}{$\begin{array}{c}\text { Logit } 2 \\
\text {-(6 yearsmodif)- }\end{array}$} & \multicolumn{2}{|c|}{$\begin{array}{c}\text { Tobit } 1 \\
----(\text { average)---- }\end{array}$} & \multicolumn{2}{|c|}{$\begin{array}{c}\text { Tobit } 2 \\
----(\text { current)---- }\end{array}$} & \multicolumn{2}{|c|}{$\begin{array}{c}\text { Linear } 1 \\
----(\text { average)---- }\end{array}$} & \multicolumn{2}{|c|}{$\begin{array}{c}\text { Linear } 2 \\
--- \text { (current)--- }\end{array}$} \\
\hline & Mg.eff & $\mathrm{p}$ & Mg.eff & $\mathrm{p}$ & Mg.eff & $\mathrm{p}$ & Mg.eff & $\mathrm{p}$ & Mg.eff. & $\mathrm{p}$ & Mg.eff & $\mathrm{p}$ \\
\hline $\begin{array}{l}\text { Experience } \\
\text { (years) }\end{array}$ & 0.035 & 0.087 & 0.0335 & 0.249 & 0.0158 & 0.042 & 0.132 & 0.137 & 0.158 & 0.092 & 0.189 & 0.051 \\
\hline $\begin{array}{l}\text { Price } \\
\text { (R\$/Liter) }\end{array}$ & 0.047 & 0.098 & 0.034 & 0.304 & -0.268 & 0.191 & -0.317 & 0.176 & -0.268 & 0.278 & -33.25 & 0.214 \\
\hline $\begin{array}{l}\text { Technical } \\
\text { assistance }\end{array}$ & -0.592 & 0.187 & - & - & - & - & - & - & - & - & 4.511 & 0.253 \\
\hline $\begin{array}{l}\text { Joint } \\
\text { purchase of } \\
\text { inputs }\end{array}$ & 0.417 & 0.017 & 0.240 & 0.163 & 5.840 & 0.023 & 5.963 & 0.042 & 5.840 & 0.059 & 5.035 & 0.170 \\
\hline $\begin{array}{l}\text { Volume } \\
\text { bonus }\end{array}$ & 0.169 & 0.33 & 0.358 & 0.080 & 1.803 & 0.435 & 1.212 & 0.647 & 1.803 & 0.518 & -0.783 & 0.803 \\
\hline $\begin{array}{l}\text { Quality } \\
\text { bonus }\end{array}$ & 0.502 & 0.024 & 0.576 & 0.007 & 3.817 & 0.098 & 2.764 & 0.295 & 3.817 & 0.170 & 3.098 & 0.311 \\
\hline $\begin{array}{l}\text { Quality } \\
\text { report }\end{array}$ & 0.755 & 0.025 & 0.408 & 0.338 & -2.665 & 0.254 & -1.278 & 0.633 & -2.665 & 0.344 & - & - \\
\hline $\begin{array}{l}\text { Payment } \\
\text { errors }\end{array}$ & 0.344 & 0.124 & - & - & - & - & - & - & - & - & - & - \\
\hline $\begin{array}{l}\text { Volume } \\
\text { (daily prod) }\end{array}$ & - & - & - & - & - & - & - & - & - & - & 0.003 & 0.039 \\
\hline $\begin{array}{l}\text { Productivity } \\
\text { (L/cow) }\end{array}$ & - & - & 0.045 & 0.284 & 0.207 & 0.426 & -0.006 & 0.984 & 0.207 & 0.509 & -0.261 & 0.452 \\
\hline $\begin{array}{l}\text { Payment } \\
\text { delay }\end{array}$ & - & - & 0.002 & 0.635 & -0.309 & 0.002 & -0.315 & 0.006 & -0.309 & 0.011 & -0.297 & 0.024 \\
\hline Cows & - & - & -0.004 & 0.315 & 0.045 & 0.128 & 0.058 & 0.092 & 0.045 & 0.207 & - & - \\
\hline
\end{tabular}

Baseline Logit 1 model prediction accuracy $=84.4 \% . \mathrm{R}^{2} \mathrm{McFadden}=0.58$. Adjusted $\mathrm{R}^{2}$ McFadden $=0.16$. Count $\mathrm{R}^{2}=0.84$. Adjusted Count $\mathrm{R}^{2}=0.61$. NS means on-significance with $\mathrm{p}>0.1$.

Logit 2 - Dependent variable is average number of consecutive years that a farmer sells milk exclusively to a given processor (same of the initial model, Logit 1).

Tobit 1 - Dependent variable is average number of years with the same processor, considering the three more recent processors.

Tobit 2 - Dependent variable is the number of years with current processor.

Linear 1 - Linear regression with dependent variable is average number of years with the same processor, considering the three most recent processors.

Linear 2 - Linear regression with dependent variable is the number of years with current processor.

opportunistic behaviors are related to the switching cost and to the dairy farmers' bargain power.

As expected, the Quality bonus positively affects farmers' loyalty according to the Baseline, Logit2 and Tobit1 models. This finding is consistent with those from a previous survey in 2010 (PRICEWATERHOUSECOOPERS, 2011), which identified drivers of loyalty creation among 463 Brazilian dairy farmers provided by quality bonus, technical assistance and mid-term forecasting prices.

The Payment delay is an important factor associated with loyalty. This variable was excluded in our Baseline model; instead, we tested Payment errors. However, in the alternative models it was statistically significant with expected signs. Farmers' propensity to switch (or not) between processors was predominantly linked to whether farmers experienced problems with delayed payments or not (FAŁKOWSKI, 2012).

The marginal effect of Price was significant in the Baseline specification but not in other estimated models. Previous studies have highlighted that paying high prices is not sufficient to increase the loyalty of suppliers (BONIFACE et al., 2012). Farmers must 
feel satisfied with the price received, that involves other dimensions such as relative prices of alternative buyers, milk quality bonus, transparency and honesty in price formation, and price-fairness (GYAU et al., 2011). CHADDAD (2007) mentioned that price is a relevant variable to enhance the loyalty of dairy farmers to cooperatives. However, other services such as the adoption of efficient communication channels with farmers are also relevant strategies to promote farmer loyalty.

Higher prices for increased production volumes did not have a statistically significant effect on farmer loyalty in our estimated models. This type of bonus is offered by most processors in Brazil, so farmers are not sensitive to this variable when choosing their milk buyer.

The statistical non-significance of the variable Technical assistance indicates that the continued technical follow-up offered by processors to farmers is not associated with an increase the loyalty. This non-significance observed for the Baseline and Linear2 models may occur because all survey farms receive free similar technical assistance service from Universidade Federal de Viçosa (UFV). According to FAŁKOWSKI (2012) technical assistance and capital access to investments provided by dairy processors to two groups of farmers with different market channels, in Poland, did not modify their willingness to change milk buyers. In contrast, BREDA \& SANTOS (2001) reported evidence that cooperation actions such as technical assistance, loans, and training programs offered to farmers generate long-term commitments and thus can reduce opportunistic behaviors.

Finally, it was expected that Payment error has a negative impact on loyalty, but the marginal effect is not statistically significant in the Baseline model formulation. The effect of this variable can be associated with the effect of the Payment delay tested in the alternative models. The establishment of a good communication channel between farmers and processors could minimize the dissatisfaction level in the commercial relationship increasing the trust and thus the loyalty as highlighted by DELIBERAL et al. (2013) and SUSANTY et al. (2017).

Two limitations of this study are the relatively small sample size and sampling only farms that are receiving technical assistance through a university. Because our sampling method was not random, and farmers belong to the same social group, the observations were completely independent. These characteristics limit the generalization of our results to other farms in the region and in Brazil. In that sense, our results should be considered exploratory and preparatory for future larger-scale studies that can assess the impact of the sample selection on the empirical results.

\section{CONCLUSION}

The loyalty of dairy farmers to processors is an issue of ongoing discussion in the Brazilian dairy supply chain and impacts chain coordination and efficiency. This study explores the determinants of loyalty of dairy farmers to the dairy processors, focusing on farmer and processor attributes in a small rural community in Minas Gerais-Brazil. This theme is little explored in the previous literature and our results indicate plausible variables that affect loyalty. We found evidence that the current milk price paid to farmers is not consistently associated with an increase the probability of loyalty to a processor, but other dimensions of satisfaction with price associated with loyalty might be considered in policy the formulation. Delayed payment is associated with reduced loyalty and payment of premiums for milk quality enhances loyalty. The payment of premiums based on milk volume was associated with loyalty. Farmers' attributes such as production scale or the technological level were not associated with loyalty. The variable years of experience have a significant association with loyalty in most of our estimated model formulations. Cooperation among farmers (e.g., joint purchase of inputs) is associated with increased likelihood of loyalty. Because all farmers in our sample received technical assistance from a university program, we cannot infer that participation in technical assistance is an important policy of processors to increase the loyalty of milk suppliers.

The limitations of our current study suggested priorities for future research, which should expand the sample size and broaden the geographic scope to include different regions in Brazil due to the regional heterogeneity. We recommend that future studies explore alternative measures of loyalty to processors and the cost implications of programs to affect loyalty, including the benefits of loyalty programs relative to the costs of acquisition of new suppliers.

\section{ACKNOWLEDGEMENTS}

We would like to thank the "Programa de Capacitação Técnica em Pecuária Leiteria da Região de Viçosa - PDPL/RV" from Universidade Federal de Viçosa" for helping with the data collection and logistics support. We also thanks the Universidade Estadual de Mato Grosso do Sul (UEMS) for partially support the publication fees. This research was conducted without funding. 


\section{DECLARATION OF CONFLICTS OF INTERESTS}

The authors declare no conflict of interest. The founding sponsors had no role in the design of the study; in the collection, analysis, or interpretation of data; in the writing of the manuscript, and in the decision to publish the results.

\section{AUTHORS' CONTRIBUTIONS}

All authors contributed equally for the conception and writing of the manuscript. All authors critically revised the manuscript and approved of the final version.

\section{REFERENCES}

ABDULAI, A.; BIRACHI, E. A. Choice of coordination mechanism in the Kenyan Fresh milk Supply Chain. Fidelização leite Logit MultinomialCusto de transação: Review of Agricultural Economics, mar. 2009. v.31, n.1, p.103-121. Available from: $<$ http://aepp.oxfordjournals.org/lookup/doi/10.111 1/j.1467-9353.2008.01428.x>. Accessed: Aug. 08, 2014

BAKUCS, L. Z.; et al. Contractual relationships in the Hungarian milk sector. British Food Journal, 8 fev. 2013. v.115, n.2, p.252-261. Available from: <http://dx.doi.org/10.1108/00070701311302221>.

BEBER, C. L. et al. Dairy supply chain in Southern Brazil: barriers to competitiveness. International Food and Agribusiness Management Review, 11 set. 2019. v.22, n.5, p.651-673. Available from: $\quad<$ https://www.wageningenacademic.com/doi/10.22434/ IFAMR2018.0091>. Accessed: Oct. 10, 2019.

BONIFACE, B. et al. Building producer loyalty in Malaysia's fresh milk supply chain. Australasian Agribusiness Review, 2010. v.18, p.66-84. Available from: <http://econpapers.repec.org/ RePEc:ags:auagre:114423>. Accessed: Aug. 09, 2014

BONIFACE, B. et al. Producer relationships segmentation in Malaysia' s milk supply chains. British Food Journal, 21 set. 2012a. v.114 n.10, p.1501-1516. Available from: $<$ http://www.emeraldinsight.com/ journals.htm?issn $=0007-070 X \&$ volume $=114 \&$ issue $=10 \&$ articleid $=1$ 7054861\&show=html $>$. Accessed: Aug. 07, 2014.

BONIFACE, B. et al. Linking price satisfaction and business performance in Malaysia's dairy industry. Asia Pacific Journal of Marketing and Logistics, 30 mar. 2012b. v.24, n.2, p.288-304. Available from: <http://www.emeraldinsight.com/ doi/10.1108/13555851211218066>. Accessed: Nov. 09, 2017.

BRAGG, L. A.; DALTON, T. J. Factors affecting the decision to Exit Dairy Farming: A Two-Stage Regression Analysis. Journal of Dairy Science, 2004. v.87, n.9, p.3092-3098. Available from: <http:// www.sciencedirect.com/science/article/pii/S002203020473444X>.

BREDA, N. L.; SANTOS, A. C. Coordenação da cadeia produtiva do leite no oeste catarinense: uma análise da interface agricultor - indústria. Ribeirão Preto, SP: [s.n.], 2001. p. 14. Available from: <http://www.fearp.usp.br/egna/resumos/BredaN pdf $>$.

BREITENBACH, R.,et al.Vantagens e oportunismo no relacionamento entre associados e cooperativa de laticínios Interações (Campo Grande), 30 maio. 2017. v.18, n.2, p.45-58.
BREITENBACH, R. . Estruturas de mercado, governança e poder na cadeia produtiva do leite no Rio Grande do Sul. Organizações Rurais \& Agroindustriais, 2015. v.17, n.3, p.336-350.

CALEMAN, S. M. De Q. et al. O setor de leite: os casos da Imbaúba e da Porto Alegre. In: MENARD, C. et al. (Org.). Economia das organizações. Formas plurais e desafios. 1. ed. São Paulo: Editora Atlas, 2014, p.216-231.

CARVALHO, M. P. De. É possível termos uma relação melhor coordenada entre produtores e indústria? Milk Point, [S.1.], 2018. Disponível em: $<$ https://www.milkpoint.com.br/colunas/marcelopereira-de-carvalho/e-possivel-termos-uma-relacao-melhorcoordenada-entre-produtores-e-industria-207836/>.

CASALI, M. et al. Information asymmetry among dairy producers in Paraná, Brazil. Semina: Ciências Agrárias, 10 jan. 2020. v.41, n.1, p.293.

CHADDAD, F. R. Cooperativas no agronegócio do leite: mudanças organizacionais e estratégicas em resposta à globalização. Organizações Rurais \& Agroindustriais, 2007. v.9, n.1, p.69-78 Available from: <http://200.131.250.22/revistadae/index.php/ora/ article/viewArticle/149>.

DELIBERAL， J. P.; TOMIELO, T.; MALAFAIA， G. C Relacionamento na Cadeia Produtiva do Leite sob a Ótica dos Laticínios. XIII Mostra de Iniciação Científica, Pós-Graduação, Pesquisa e Extensão UCS. Available from: <http://www.ucs. br/etc/conferencias/index.php/mostraucsppga/mostrappga2013/ paper/viewFile/3580/1116>

DURLO, P. M. Análise da viabilidade econômica e financeira para uma agroindústria de laticínios na cidade de Santo Augusto. [S.1.]: Universidade Regional do Noroeste do Estado do Rio Grande do Sul, 2012.

EL-OSTA, H. S.; MOREHART, M. J. Technology Adoption and Its Impact on Production Performance of Dairy Operations. Review of Agricultural Economics, 2000. v.22, n.2, p.477-498. Available from: $<$ http://www.jstor.org/stable/1349806>.

FAŁKOWSKI, J. Vertical coordination, access to capital, and producer loyalty in the Polish dairy sector. Fidelização: Agricultural Economics, mar.2012. v.43, n.2, p.155-164. Available from: <http://search.proquest.com/docview/10183316 26? accountid $=13042 \% 5 \mathrm{Cnhttp}$ //oxfordsfx.hosted.exlibrisgroup. com/oxford?url_ver=Z39.88-2004\&rft_val_fmt=info:ofi/fmt:kev :mtx:journal\&genre=article\&sid=ProQ:ProQ $\bar{Q}$ :econlitshell\&atitle= Vertical + Coordination,+ Access + to $+C>$

GACHANGO, F. G.; et al. Adoption of milk cooling technology among smallholder dairy farmers in Kenya. Tropical Animal Health and Production, 2014. v.46, n.1, p.179-184.

GYAU, A.; SPILLER, A.; WOCKEN, C. Price or relational behaviours?: Supplier relationship management in the German dairy industry. British Food Journal, 7 maio. 2011. v. 113, n. 7, p. 838-852. Available from: <http://www.emeraldinsight.com/ journals.htm issn $=0007-070 \mathrm{X} \&$ volume $=113 \&$ issue $=7 \&$ articleid $=$ 1937581\&show=html>. Accessed: Aug. 12, 2014.

INSTITUTO BRASILEIRO DE GEOGRAFIA E ESTATÍSTICA IBGE. Censo Agropecuário. Brasília: Instituto Brasileiro de Geografia e Estatística - IBGE, 2017. Available from: <https://sidra.ibge.gov.br>. 
MARASCHIN, Â. De F.; WAQUIL, P. D. As relações entre produtores de leite e cooperativas : um estudo de caso na bacia leiteira de Santa Rosa-RS. Rio Grande do Sul: Universidade Federal do Rio Grande do Sul, 2004. Available from: <http:// www.lume.ufrgs.br/bitstream/handle/10183/6407/000485056. pdf? sequence $=1>$.

MUTONYI, S. et al. Price satisfaction and producer loyalty: the role of mediators in business to business relationships in Kenyan mango supply chain. British Food Journal, 2016. v.118, n.5, p.1067-1084. Available from: $<$ http://www.emeraldinsight.com/doi/10.1108/BFJ-092015-0319>.

PRICEWATERHOUSECOOPERS. Fatores críticos de sucesso na cadeia láctea. [S.1.], 2011. Available from: <http://www.pwc. com.br/pt/publicacoes/setores-atividade/agribusiness/pesquisamilkpoint-pwc.jhtml>.

ROGERS, E. M. Diffusion of Innovations. 5th. ed. New York: Simon and Schuster, 2003.

SCALCO, P. R.; BRAGA, M. J. Measuring the Degree of Oligoposony Power in the Brazilian Raw Milk Market. International Food and Agribusiness Management Review, 2014. v.17, n.2, p.20.

SEBRAE-ES. Usina de beneficiamento de leite. Serie perfil de projetos. Vitória: [s.n.], 1999.

SILVA, J. R. Da et al. Understanding the intention of smallholder farmers to adopt fish production. Aquaculture Reports, jul. 2020. v.17, p.100308. Available from: <https://linkinghub.elsevier.com/ retrieve/pii/S2352513419303412>.

SILVA, L. H. A. Da; CAMARA, M. R. G. Da; TELLES, T. S. Evolution and spatial distribution of dairy production in Paraná State, Brazil. Acta Scientiarum. Human and Social Sciences, 2016. v.38, n.1, p.37-47.

SIMÕES, A.R.P.; PROTIL, R.M. Revelação das preferências dos produtores de leite na escolha de um laticínio: Uma abordagem Multicritério, in: $53^{\circ}$ Congresso Da Sociedade Brasileira de Economia Administração e Sociologia Rural - SOBER. João Pessoa - PB, p. 16.

SIMÕES, A. R. P. et al.. The Technological heterogeneity of dairy farming in Minas Gerais. Agrarian, 20 fev.2017. v.10, n.38, p.261-269. Available from: <http://ojs.ufgd.edu.br/index.php/ agrarian/article/view/6782>. Accessed: Mar. 08, 2018.

SUSANTY, A.; BAKHTIAR, A.; MUTI, M. Empirical model of trust, loyalty, and business performance of the dairy milk supply chain: a comparative study. British Food Jurnal, 12 out. 2017. v.19, n.12, p.2765-2787. Available from: <http://www.emeraldinsight. com/doi/10.1108/BFJ-10-2016-0462>. Accessed: Oct. 19, 2017.

TELLES, T. S.; BACCHI, M. D.; SHIMIZU, J. Spatial distribution of microregions specialized in milk production. Semina: Ciências Agrárias, 2017. v.38, n.1, p.443-454.

WATTS, D. J.; DODDS, P. S. Influentials, Networks, and Public Opinion Formation. The Journal of Consumer Research, 2007. v.34, n.4, p.441-458. Available from: <http://cdg.columbia.edu/ uploads/papers/watts2007_influentials.pdf $>$. 